\title{
Cara Menghadapi Emosi Anak ADHD bagi Orang Tua dan
}

\section{Pendidik}

\author{
Ersa Srivi Wulan Suci ${ }^{1, *}$, Nur Hazizah ${ }^{1}$ \\ ${ }^{1}$ Pendidikan Guru Pendidikan Anak Usia Dini, Fakultas Ilmu Pendidikan, Universitas Negeri Padang, \\ Padang, Indonesia \\ ${ }^{(*)}$ ersasriviwulansuci@gmail.com
}

\begin{abstract}
ABSTRAK
Emosi merupakan perasaan yang bergejolak ada pada diri individu. Pada anak usia dini emosi berguna untuk menyampaikan atau mengekspresikan perasaan yang saat itu dirasakan. Namun pada anak yang menderita ADHD perasaan emosinya sering sekali tidak terkontrol. Karena anak ADHD ini adalah anak yang memiliki tingkat konsentrasi dan titik focus yang sangat rendah sekali. Oleh sebab itu hendaknya kita sebagai orang tua dan guru harus memahami keadaan anak tersebut agar kita bisa dapat menghadapi anak tersebut. karena minimnya pengetahuan oleh orang tua dan pendidik akan perkembangan emosi pada anak ADHD ini, anak ADHD ini sering sekali dikatakan anak nakal karena sifatnya yang tidak bisa diam dan selalu bergerak. Atau sering dikatakan orang anak yang hiperaktif.
\end{abstract}

\section{PENDAHULUAN}

Emosi merupakan perasaan yang ada pada setiap diri individu baik pada orang dewasa maupun pada anak-anak. Emosi merupakana perasaan yang bergejolak pada setiap diri individu yang mengakibatkan perubahan pada ekspresi wajah, perasaan, yang akhirnya akan mengakibatkan aksi ntuk melampiaskan emosi tersbeut. Seperti menangis, tertawa, terharu, marah, dan lain sebagainya. Emosi tersebut terjadi akibat adanya stimulus yang diterima oleh individu tersebut dari luar yang mengakibatkan aksi tersbut terjadi. Hal ini seiring dengan pendapat Chaplin ( Dalam Safaria \& Saputr, 2012).
ADHD merupakan gangguan pemusatan perhatian dan hiperaktifitas pada anak. Disini terlihat anak tidak bisa diam dan selalu bergerak. Seiring dengan pendapat (Paternotte \& Buitelaar, 2010) yang mengatakan bahwa anak ADHD merupakan anak yang selalu bergerak disetiap harinya dan tidak dapat duduk diam. Anak hiperaktif ini memiliki tingkat konsentrasi yang sangat singkat. Karena kurangnya pemahaman oleh orang tua dan pendidik mengenai anak ini, terkadang anak ini sering dikatakana nak nakal, anak yang tidak bisa diatur, dan lain sebagainya. ADHD ini biasanya disebabkan oleh faktor keturunan, faktor genetic, dan faktor lingkungan. Solusi untuk menghadapi anak 
ADHD ini yaitu hendaknya orang tua dan pendidik paham akan keadaan anak ini, selalu berpikir positif tentang si anak, saat anak melakukan kesalahan hendaknya memberikan hukuman yang masuk akal seperti membiarkan anak untuk merenung dan menyadari kesalahannya pada pojok ruangan. Dan pada saat anak melakukan hal yang baik dan benar, tidak ada salahnya juga untuk memberikan penghargaan pada si anak. dengan adanya pemahaman dari orang tua maupun pendidik dan kerja sama antara orang tua dan pendidik, maka hal tersebut akan memberikan dampak positif bagi anak dan ADHD pada anak tersebut membaik.(Paternotte \& Buitelaar, 2010)

\section{KAJIAN TEORI}

\section{Sifat dan Karakter Anak Usia Dini}

Karakter dan sifat dari seorang anak tersebut tergantung dari faktor-faktor yang mempengaruhi anak. Baik itu faktor internal, maupun faktor eksternal. Yang dimaksud dengan faktor internal. Jika faktor internal dan faktor eksternal anak tersebut baik, maka sifat dan karakter seorang anak itu akan baik juga. Tetapi sebaliknya jika faktor yang mempengaruhi anak tersebut tidak baik, maka sifat dan karakter anak akan tidak baik juga. Hal tersebut siring dengan pendapat Jean Piaget ( Dalam Paternotte \& Buitelaar, 2010) yang menyatakan bahwa anak membangun pengetahuan dari lingkungan sekitar anak tersebut.

Selain lingkungan yang mempengaruhi sifat dan karakter anak tersebut, orang-orang yang ada di sekitar anak juga sangat mempengaruhi sifat dan karakter anak. Bagaimana cara orang disekitar anak tersebut berbicara, anak juga akan berbicara seperi itu misalnya jika keluarga anak tersebut sering berbicara dengan nada tinggi, maka anak juga akan berbicara dengan nada tinggi juga. Jika keluarga anak berbicara dengan kata-kata kasar, maka anak juga akan berbicara kasar. Hal ini seiring dengan pendapat Vigotsky ( Dalam Hrjaningrum, 2007)yang menyatakan bahwa pembelajaran dicapai oleh anak dalam interaksi sosial.

Sifat dan karakter anak juga dipengaruhi oleh orang-orang yang ada disekitar anak, maksudnya adalah orangorang yang ada disekitar anak akan jadi model yang akan ditiru oleh anak misalnya ayah anak tersebut merupakan sesorang yang pemarah. Saat marah si ayah akan melemparkan sesuatu akan membanting sesuatu. Anak akan berpikir jika marah harus melemparkan dan membanting sesuatu. Hal tersebut akan dilakukana anak saat melihat ayahnya. Ini seiring dengan pendapat ahli Bandura (dalam Hrjaningrum, 2007) yang menyatakan bahwa prilaku seorang anak tersebut dipelajari dari sesuatu yang ditiru yang dijadikan model.

\section{Pengertian Emosi}

Emosi adalah rasa yang ada pada diri setiap idividu baik orang dewasa maupun anak usia dini. emosi merupakan perasaan yang bergejolak yang ada didalam diri seseorang yang ditimbulkan akibat adanya stimulus atau rangsangan yang datang dari luar diri yang mengakibatkan perubahan pada ekspresl wajah, detak jantung, reaksi tubuh yang mendorong untuk melakukan sesuatu baik itu menangis, tertawa, marah dan lain sebagainya. Hal ini seiring dengan pendapat Chaplin (dalam Safaria \& Saputr, 2012). Oleh sebab itu hendaknya kita sebagai orang tua harus mengembangkan emosi anak usia dini melalui sosialisasi orang tua seperi pemodelan untuk anak usia dini, kontingensi dan pembinaan. Hal ini ssependapat dengan (Wandansari, Suminar, \& Afiatin, 2016)

$\begin{array}{cccc}\text { Bagi } & \text { anak } & \text { usia dini } & \text { emosi } \\ \text { merupakan } & \text { cara } & \text { mereka } & \text { untuk }\end{array}$


menyampaikan perasaan yang mereka rasakan, mengekspresikan perasaan dan memberitaukan orang yang ada disekitar mereka tentang apa yang sedang mereka rasakan pada saat itu dengan cara memperlihatkan reaksi luar yang mereka berikan. Seiring dengan pendapat nya yang menyatakan bahwa hendaknya orang tua mampu memahami perasaan anak melalui ekspresi yang mereka perlihatkan.(Qodariah \& Pebriani, 2016)

Untuk itu kita sebagai orang tua maupun pendidik hendaknya mampu mengembangkan emosi anak tersebut dengan baik. Cara untuk mengembangkan emosi anak dapat kita lakukan dengan berbagai cara. Salah satu cara yang sangat disukai oleh anak adalah dengan menggunakan metode bermain. Karena tida ada satupun anak yang tidak suka dengan yang namanya bermain. Yang seiring dengan pendapat dari nya yang menyatakan bahwa salah satu cara pengembangan emosi pada anak dapat dilakukan dengan cara bermain. (Hazizah, 2018)

\section{Pengertian Attention Deficit Hyperactivity Disorder (ADHD)}

ADHD merupakan salah satu penyakit yang ada pada anak usia dini diman anak tersebut memiliki tingkat konsentrasi atau titik focus yang sangat rendah. Anak ini juga sangat aktif dan tidak bisa diam pada satu tempat dalam waktu lama. Anak ini tidak akan terus bergerak sepanjang hari. Anak-anak yang menderita ADHD ini biasanya tidak akan bisa tenang dan lebih mudah frustasi . anak ini akan membutuhkan banyak energy untuk bisa duduk diam pada satu titik untuk waktu yang lama. Pendapat ini seiring dengan Arga Paternotte, Jan Buitelaar (2010:4) yang menyatakan bahwa anak ADHD akan selalu bergerak sepanjang hari dan tidak akan dapat duduk diam dikursinya. Anak ADHD ini juga dikatakan dengan anak yang hyperaktife yang mana anak ini memiliki pola respos yang lambat dengan kecepatan yang tidak akurat akurat. Hal ini seiring dengan pendapat (Kuntsi \& Stevenson, 2000)

Beberapa cara yang dapat dilakukan untuk menghadapi anak yang menderita ADHD ini adalah

- Selalu Berpikir Positif Mengenai Anak

orang tua maupun pendidik hendaknya kita selalu berpikir positif mengenai anak ini karena dengan kita berpikir positif tentang si anak, saat anak telah melakukan kekacauan ataupun kesalahan yang sangat banyak kita dapat menahan diri agar tidak marah. Hal tersebut dilakukan karena anak yang menderita ADHD tersebut memiliki kebutuhan akan diri kita untuk memberikannya dukungan agar selalu percaya diri. Jadi disini kita dituntut untk sabar menghadapi anak ini. Salah satu caranya, dengan selalu berpikir positif tentang si anak. Karena itu akan membantu mengembalikan kepercayaan diri si anak.

- Penghargaan dan Hukuman

Bagi anak penderita ADHD bukan berarti semua kesalahan yang dilakukannya semuanya dibiarkan dan dimaklumi. Tetap saja esuatu yang salah tetap salah. Oleh sebab itu kita sebagai orang tua maupun pendidik hendaknya selalu konsisten akan hukuman yang diberikan dan antara ayah dan ibu juga harus konsisten. Jangan sampai saat anak tersebut melakukan kesalahan dengan si ayah anak mendapatkan hukuman tetapi saat anak melakukan kesalahan dengan si ibu, anak tidak diberikan hukuman. Hal tersebut 
tidak boleh dilakukan. Antara ayah dan ibu harus konsisten memberikan hukuman saat anak melakukan kesalahan. Tentu saja hukuman yang diberikan kepada anak ini juga hukuman yang masuk akal dan tidak membahayakan bagi anak. Contoh hukumannya misalnya adalah pada saat anak bangun pagi dan membereskan tempat tidur anak akan diberikan bintang. Tetapi saat anak tidak membereskan tempat tidurnya, anak tidak akan mendapatkan apaapa.

Begitu juga dengan penghargaan saat anak melakukan hal yang baik dan benar, tidak ada salahnya jika anak diberikan penghargaan yang dapat memotifasi kembali anak untuk berbuat baik. Penghargaan yang diberikan kepada anak juga akan membuat anak tersebut untuk selalu berbuat baik dan benar. Misalnya saja saat anak membuang sampah pada tempatnya, anak diberikan pujian.

\section{- $\quad$ The Time Out}

Maksudnya disini adalah the time out merupakan suatu metode yang digunakan untuk merenung dan memikirkan kembali kesalahan yang telah kita lakukan. Pada anak ADHD hal ini dilakukan guna untuk agar anak dapat menyedari kesalahannya tanpa kita harus marah kepada anak tersebut. cukup kita biarkan anak pada pojok ruangan misalnya katakana kepada anak tersebut pikirkan kesalahan yang telah kamu lakukan barusan setelah itu baru boleh duduk dekat kita kembali dan membicarakan kesalahan tersebut.

- Peraturan dan Struktur
Bagi anak yang menderita ADHD peraturan merupakan salah satu hal yang sangat sulit dipatuhi. Namun hendaknya kita dapat menjalankan ini pada anak ADHD guna untuk membentuk konsep diri pada anak. Peraturan dan struktur digunakan sebagai alat bantu untuk anak ini. Peratutan yang diberikan harus jelas dan singkat dan dimulai dengan langkah kecil dan juga dilakukan dengan cara perlahan. Misalnya setelah makan makanan yang menggunakan bungkus plastic, sampahnya harus di buang ke tong sampah. Untuk anak normal hal itu cukup dilakukan dengan cara berbicara saja. Namun untuk anak ADHD ini kita perlu memperlihatkan contohnya melihatnya melakukan hal tersebut, dan selalu mengulang-ulang hal tersebut hingga anak itu terbiasa sendiri.

- Penjelasan kepada Keluarga

\begin{tabular}{ccr}
\multicolumn{2}{c}{ Maksudnya } & adalah \\
hendaknya $\quad$ setiap & keluarga
\end{tabular} memahami keadaan anak ini. Hal tersebut bertujuan untuk agar kita dapat membentuk konsep diri anak dengan baik dan benar. Semua anggota keluarga hendaknya bekerja sama untuk membantu anak ini. Kita sebagai orang tua dapat memberitaukan kepada anggota keluarga akan peraturan-peraturan baru yang dibuat untuk membantu anak yang menderita ADHD ini.

Itulah beberapa cara yang dapat dilakukan oleh orang tua dan guru guna untuk membantu anak yang menderita ADHD tersebut. seiring dengan pendapat (Paternotte \& Buitelaar, 2010) 


\section{PEMBAHASAN}

Emosi pada anak usia dini merupakan perasaan yang timbul dari dalam diri anak akibat adanya stimulu dari luar yang mengakibatkan timbulnya reaksi pada anak seperti raut wajah yang berubah, jantung berdetak kencang, dan bahkan menimbulkan aksi seperti marah, menangis, tertawa dan lain sebagainya. Disini penulis akan membahas bagaimana emosi pada anak yang menderita Attention Deficet Hyperaktiveity Disorder atau yng lebih dikenal dengan ADHD dan cara menanganinya bagi guru dan orang tua. Dimana anak yang menderita ADHD ini memiliki tingkat konsentrasi yang sangat singkat sekali. Anak ini selalu bergerak sepanjang hari dan tidak bisa diam dalam satu titik untuk waktu yang lama. Untuk diam tersebut mereka akan membutuhkan energy yang sangat besar sekali.

Bagi orang tua dan guru yang tidak memahami kondisi dan keadaan anak ini, karena sikapnya yang seperti ini anak ADHD ini sering sekali dikatakan anak nakal. Padahal hal tersebut sudah menjadi karakter anak dan hendaknya guru dan orang tualah yang harus mengerti dan harus paham akan kondisi anak dan membantu anak agar dapat membentuk konsep diri. Karena jika tidak orang tua dan guru yang akan membantu anak, lalu siapa lagi.Anak yang menderita ADHD ini pada saat belajar akan membuat guru kerepotan karena anak ini tidak bisa diam dan dapat mengganggu teman-temanya yang lain pada saat belajar. Hal tersebut mengakibatkan tujuan pembelajaran tidak akan tercapai dengan baik.(Suharmini, 2004)

ADHD ini biasanya disebabkan oleh beberapa faktor seperti yang telah dijelaskan oleh (Paternotte \& Buitelaar, 2010) diantaranya :

- Faktor keturunan
Maksudnya adalah pada orang tua yang sebelumnya menderita ADHD $80 \%$ kemungkinan anaknya juga akan menderita ADHD tersebut.

- Faktor genetic dan lingkungan

Maksudnya adalah ADHD ini juga tergantung kepada gen dan efek negative dari lingkungannya tersebut. lingkungan yang dimaksud disini adalah misalnya pada lingkungan psikologis yang di antaranya relasi yang ada disekitar anak seperti teman, orang tua, dan keluarga. Lingkungan fisik misalnya seperti makanan, obat-obatan. Lingkungan biologis maksudnya adalah apakah anak pernah mengalami cidera pada otaknya.

- ADHD dan otak

Maksudnya disini adalah sangat jelas bahwa kaitan secara lingkungan biologis yang mana hal tersebut melibatkan otak

\section{KESIMPULAN}

Emosi pada anak yang menderita ADHD ini harus ditangani oleh orang-orang yang ada disekiatar anak dengan benar agar dapat membentuk konsep diri pada anak yang menderita ADHD tersebut. hal tersebut dapat dilakukan oleh kerja sama antara guru, orang tua dan keluarga yang membutuhkan kesabaran yang ekstra untuk menghadapi anak tersebut. cara yang dapat dilakukan adalah diantaranya berpikir positif tentang anak, memberikan penghargaan dan hukuman bagi anak, memberikan peraturan yang struktur pada anak, dan menjelaskan keadaan anak pada anggota keluarga agar keluarga paham juga bagaimana cara menghadapi anak tersebut. 


\section{REFERENSI}

Hazizah, N. (2018). The Importance of Playing for Developing Intelligence in Early Childhood, 169(Icece 2017), 213-215.

Hrjaningrum, agnes tri. (2007). peranana orang tua dan praktisi dalam membantu tumbuh kembang anak berbakat melalui pemahaman teori dan tren pendidikan (1st ed.). jakarta: prenada media grup.

Kuntsi, J., \& Stevenson, J. (2000). Hyperactivity in children: a focus on genetic research and psychological theories. Clinical Child and Family Psychology Review, 3(1), 1-23. https://doi.org/10.3389/fmicb.2015.013 59

Paternotte, A., \& Buitelaar, J. (2010). ADHD Attention Defict Hyperactivity Disorder. (A. . Anwar, Ed.) (1st ed.). jakarta: kencana.

Qodariah, L., \& Pebriani, L. V. (2016). Recognizing Young Children's Expressive Styles of Emotions (2-6 Years Old). Proceedings of the $3 R d$ International Conference on Early Childhood Education (Icece 2016), 58, 254-261.

Safaria, T., \& Saputr, N. E. (2012). menejemen emosi. jakarta: PT bumi aksara.

Suharmini, T. (2004). penanganan anak hiperaktif melalui etode sensory integrative therapy. yogyakarta.

Wandansari, Y., Suminar, D. R., \& Afiatin, T. (2016). Optimizing the Development of Emotional Competence in Early Childhood. Proceedings of the $3 R d$ International Conference on Early Childhood Education (Icece 2016), 58, 475-481. 